\title{
KERAGAAN BUDIDAYA TAMBAK DI SULAWESI SELATAN DENGAN MENGGUNAKAN DATA SENSUS
}

\author{
Akhmad Mustafa, Irmawati Sapo, dan Mudian Paena \\ Balai Riset Perikanan Budidaya Air Payau \\ Jl. Makmur Dg. Sitakka No. 129, Maros, Sulawesi Selatan 90512 \\ E-mail: akhmadmustafa@yahoo.com
}

\section{ABSTRAK}

Data sensus yang runut waktu dari perikanan budidaya tambak telah tersedia yang diharapkan dapat digunakan semaksimal mungkin agar dapat memberikan informasi yang maksimal pula. Oleh karena itu, dilakukan suatu kegiatan yang memanfaatkan data runut waktu dari perikanan budidaya tambak di Sulawesi Selatan untuk menginformasikan keragaan budidaya tambak termasuk daya dukung ekonomis tambak. Data yang digunakan adalah data yang berasal dari Laporan Statistik Perikanan Sulawesi Selatan dari tahun 1985 sampai 2004. Keragaan budidaya tambak yang diinformasikan meliputi: perubahan luas, produksi dan produktivitas tambak pada tiga pantai yang berbeda di Sulawesi Selatan serta produksi berdasarkan kelompok komoditas. Analisis daya dukung ekonomis tambak ditentukan dengan metode analisis regresi polinomial. Hasil kegiatan ini menunjukkan bahwa luas tambak di Sulawesi Selatan (termasuk Sulawesi Barat) meningkat dari 64.741 ha pada tahun 1985 menjadi 111.425 ha pada tahun 2004 . Produksi total tambak tertinggi pada tahun 1985 didapatkan di pantai barat yang mencapai $26.323,9$ ton yang didominasi oleh ikan dan pada tahun 2004 didapatkan di pantai timur yang mencapai $66.294,1$ ton yang didominasi oleh rumput laut. Produktivitas tambak tertinggi pada tahun 1985 didapatkan di pantai barat yaitu $772,2 \mathrm{~kg} / \mathrm{ha} / \mathrm{tahun}$ dan pada tahun 2004 didapatkan di pantai timur yaitu $7.127,6$ kg/ha/tahun. Lahan Kabupaten Pinrang yang merupakan sentra produksi tambak di Sulawesi Selatan, hanya bisa mendukung luas total tambak sekitar 13.136 ha dan daya dukung ekonomis tambak hanya bisa memproduksi udang dan ikan sekitar $1.286 \mathrm{~kg} / \mathrm{ha} / \mathrm{tahun}$.

KATAKUNCl: sensus, keragaan, tambak, Sulawesi Selatan

\section{PENDAHULUAN}

Jenis perikanan budidaya yang dilakukan di Indonesia meliputi budidaya laut, budidaya tambak (air payau), budidaya kolam, dan budidaya sawah. Di antara berbagai jenis perikanan budidaya tersebut, produksi tertinggi yaitu 559.612 ton $(38,10 \%$ dari total produksi perikanan budidaya) berasal dari budidaya tambak dengan luas mencapai 489.811 ha (luas kotor) pada tahun 2004 (Anonim, 2006). Usaha perikanan budidaya tambak merupakan kegiatan yang memanfaatkan kawasan pesisir yang mampu memberikan kontribusi cukup besar terhadap pendapatan masyarakat pesisir, penyedia lapangan kerja, dan perolehan devisa negara yang potensial. Sulawesi Selatan (tidak termasuk Kabupaten Polmas, Majene, dan M amuju yang sekarang ini termasuk Sulawesi Barat) merupakan salah satu sentra produksi budidaya tambak dan memiliki tambak terluas di Indonesia yaitu 98.617 ha (Anonim, 2008). Secara geografis, tambak-tambak di Sulawesi Selatan didapatkan di pantai barat, selatan, dan timur yang masing-masing memiliki kondisi lahan yang berbeda.

Metode sensus adalah salah satu metode yang sering digunakan dalam pengumpulan data, termasuk penentuan luas tambak. Metode sensus memiliki kelebihan terutama hemat dalam waktu dan biaya tetapi kelemahan yang mungkin terjadi adalah munculnya bias data yang sangat besar. Namun demikian, data sensus dari perikanan budidaya tambak ini diharapkan dapat memberikan gambaran tentang keragaan budidaya tambak di Sulawesi Selatan. Selain itu, dengan penggunaan data runut waktu (times series) diharapkan pula dapat memberikan gambaran yang lebih jelas mengenai keragaan budidaya tambak di Sulawesi Selatan.

\section{BAHAN DAN METODE}

Data yang digunakan adalah data yang berasal dari Laporan Statistik Perikanan Sulawesi Selatan selama dua dekade terakhir (dari tahun 1985 sampai 2004) (Anonim 1985-2004), sebelum Provinsi Sulawesi Selatan 
dimekarkan menjadi Provinsi Sulawesi Selatan dan Sulawesi Barat. Data yang digunakan meliputi: luas kotor tambak serta produksi tambak dari setiap kabupaten. Produktivitas tambak ditentukan dengan menggunakan rumus:

$$
\text { Produktivitas tambak }=\frac{\text { Produksi total tambak }}{\text { Luas tambak }}
$$

Data yang diperoleh dikelompokkan berdasarkan letak geografis tambak di Sulawesi Selatan yaitu: di pantai barat (Kabupaten Gowa, Kota Makassar, Kabupaten Maros, Kabupaten Pangkep, Kabupaten Barru, Kota Parepare, Kabupaten Pinrang, Kabupaten Polmas, Kabupaten Majene, dan Kabupaten Mamuju), pantai selatan (Kabupaten Takalar, Kabupaten Jeneponto, Kabupaten Bantaeng, Kabupaten
Bulukumba, dan Kabupaten Selayar) dan pantai timur (Kabupaten Sinjai, Kabupaten Bone, Kabupaten Wajo, Kabupaten Luwu, Kota Palopo, Kabupaten Luwu Utara, dan Kabupaten Luwu Timur) (Gambar 1). Data juga dikelompokkan berdasarkan jenis produksi yaitu: ikan, krustase dan rumput laut. Yang termasuk kelompok produksi ikan adalah: bandeng (Chanos chanos), belanak (Mugil sp.), kakap (Lutjanus sp.), mujair (Tilapia mossambica), sidat (Anguilla sp.) dan ikan lainnya, sedangkan yang termasuk kelompok produksi krustase adalah: udang windu (Penaeus monodon), udang putih (Penaeus merguensis), udang api-api (M etapenaeus ensis), rebon (Mysis sp.), kepiting (Scylla sp.) dan rajungan (Portunus pelagicus). Dalam kelompok rumput laut hanya termasuk rumput laut jenis Gracilaria verrucosa. Seluruh data ditampilkan dalam bentuk grafik.

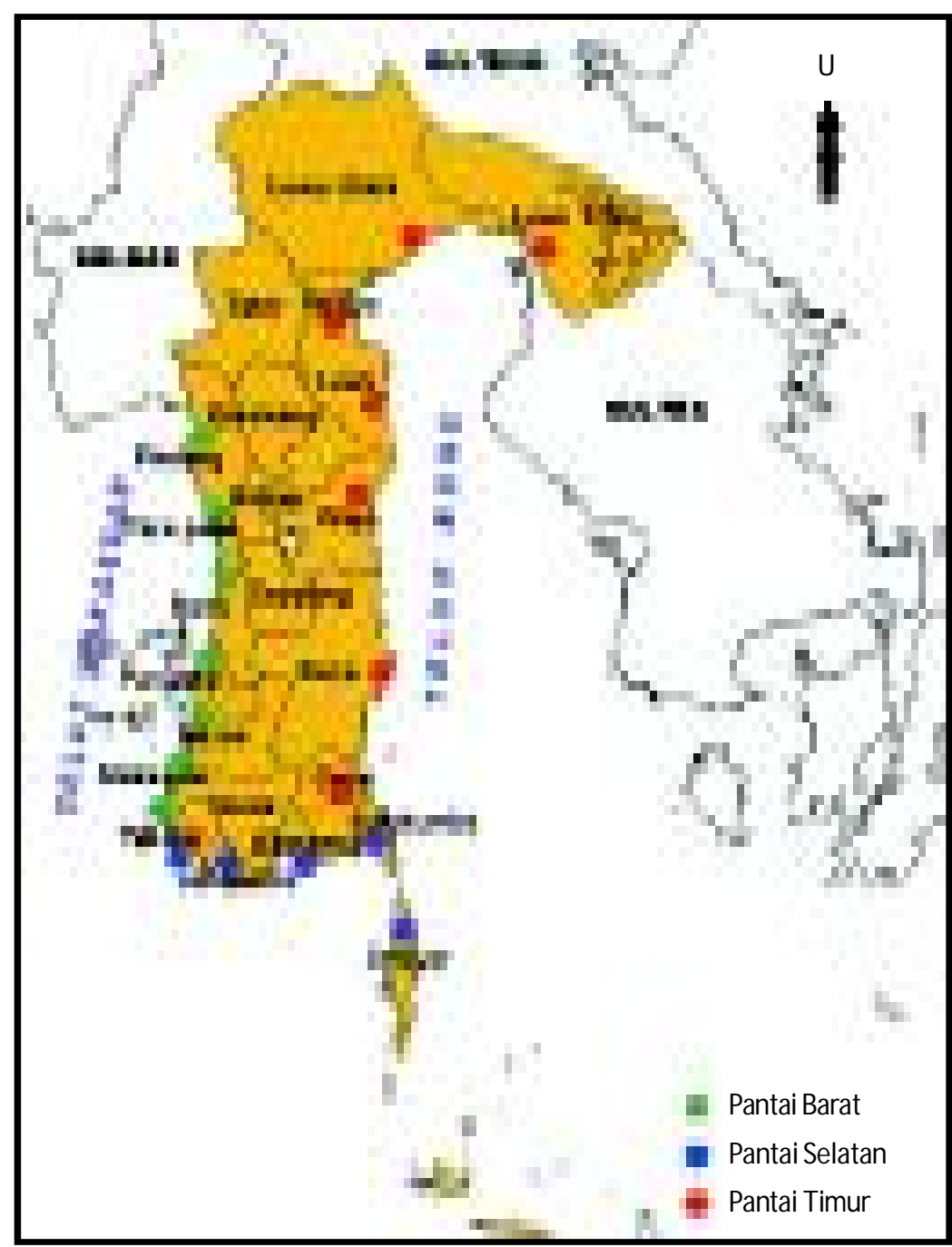

Gambar 1. Pembagian secara geografis dari setiap kabupaten yang memiliki lahan budidaya tambak di Sulawesi Selatan (termasuk Sulawesi Barat) 
Metode analisis regresi polinomial pada penelitian ini dimaksudkan untuk memprediksi luas lahan pertambakan yang dapat didukung secara ekonomis. Metode analisis regresi (Sudjana, 1996) adalah sebagai berikut:

$Y=a+b X+c X^{2}$

Persamaan 1

di mana:

$Y=$ Produktivitas tambak $(\mathrm{kg} / \mathrm{ha})$

$X=$ Luas tambak (ha)

dengan menggunakan metode kuadrat terkecil, maka $a, b$ dan c dapat dihitung dari persamaan:

$$
\begin{aligned}
& \Sigma Y_{i}=n a+b \Sigma X_{i}+c \Sigma X_{i}^{2} \quad \text { Persamaan 2 } \\
& \Sigma X_{i} Y_{i}=a \Sigma X_{i}+b \Sigma X_{i}^{2}+c \Sigma X_{i}^{3} \quad \text { Persamaan } 3 \\
& \Sigma X_{i}^{2} Y=a \Sigma X_{i}^{2}+b \Sigma X_{i}^{3}+c \Sigma X_{i}^{4} \quad \text { Persamaan } 4
\end{aligned}
$$

Koefisien determinasi atau koefisien penentu $\left(R^{2}\right)$ dihitung dengan menggunakan rumus (Sudjana, 1996):

$$
R^{2}=\frac{b\left\{n \Sigma X_{i} Y_{i}-\left(\Sigma X_{i}\right)\left(\Sigma Y_{i}\right)\right\}}{n \Sigma Y_{i}^{2}-\left(\Sigma Y_{i}\right)^{2}} \quad \text { Persamaan } 5
$$

di mana:

$\mathrm{R}^{2}=$ Koefisien determinasi

$Y=$ Produktivitas tambak $(\mathrm{kg} / \mathrm{ha})$

$X=$ Luas tambak (ha)

\section{HASIL DAN BAHASAN}

Dari 23 kabupaten/kota yang ada di Sulawesi Selatan, ternyata tambak dijumpai di 19 kabupaten/kota dan hanya 4 kabupaten yang tidak memiliki tambak yaitu Kabupaten Soppeng, Sidrap, Enrekang, dan Tator. Luas tambak di Sulawesi Selatan pada tahun 1985 mencapai 64.741 ha yang dapat dijumpai seluas 27.979 ha di pantai barat, 8.865 di pantai selatan dan sisanya sebesar 27.900 ha di pantai timur. Pada tahun 2004, luas tambak di Sulawesi Selatan mencapai 111.424 ha, di mana 53.715 ha di antara dijumpai di pantai barat, 16.759 di pantai selatan dan 40.950 ha di pantai timur (Gambar 2).

Peningkatan luas tambak terbesar selama dua dekade terjadi di pantai barat yaitu 25.739 ha atau $1.286,95$ ha/tahun kemudian disusul di pantai timur seluas 13.050 ha. Tingginya peningkatan luas tambak di pantai barat sebagai akibat adanya konversi lahan mangrove menjadi tambak yang cukup besar di Kabupaten Mamuju dan konversi lahan sawah menjadi tambak di Kabupaten Maros, Pangkep, dan Pinrang. Sebagai contoh, hasil analisis dengan Sistem Informasi Geografis (SIG) yang dilakukan oleh Mustafa et al. (2006) menunjukkan bahwa luas tambak di Kabupaten Maros dan Pangkep pada tahun 1991 berturut-turut 7.184,3 dan 7.779,4 ha dan meningkat masing-masing menjadi $9.587,7$ dan $13.494,8$ ha sampai pada tahun 2002. Dikatakan pula bahwa, penambahan luas tambak di kedua kabupaten tersebut sebagian besar berasal dari konversi sawah dan sebagian lagi berasal dari konversi penggunaan lahan lainnya yang ada di kawasan pesisir. Hasil analisis dengan SIG juga menunjukkan bahwa luas tambak di Kabupaten Pinrang pada tahun 1991 adalah 7.490,8 ha dan meningkat pada tahun 2002 dan 2005 menjadi berturut-turut 13.366,1 dan 14.569,2 ha. Penambahan luas tambak sebagian besar berasal dari konversi sawah ada di kawasan pesisir Kabupaten Pinrang. Konversi penggunaan lahan didorong oleh pertumbuhan penduduk, peningkatan pendapatan, kegiatan ekonomi, dan migrasi dari wilayah lain maupun wilayah belakang kota di wilayah bersangkutan (Nasoetion \& Wagner, 1985). Perubahan penggunaan lahan terutama berkorelasi dengan laju pertumbuhan penduduk, kondisi ekonomi pertanian,

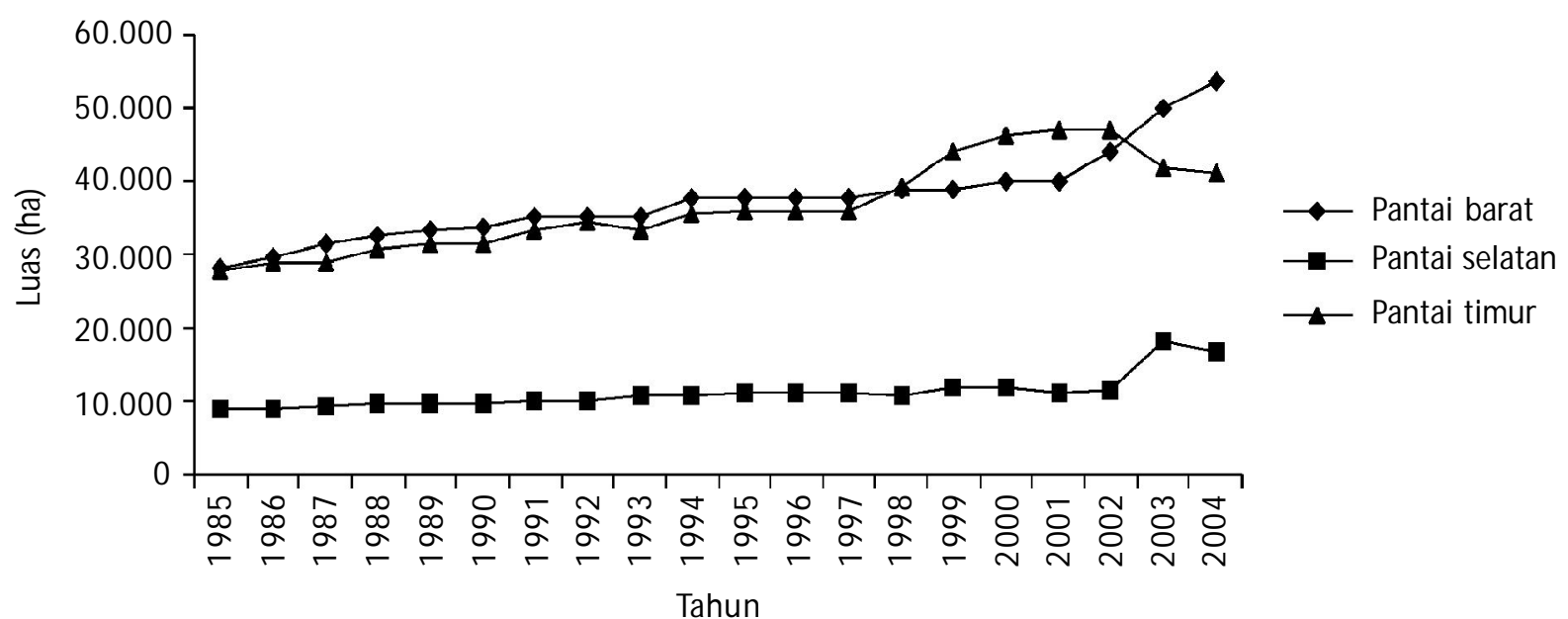

Gambar 2. Luas tambak pada pantai yang berbeda di Sulawesi Selatan dari tahun 1985 sampai 2004 
level kemakmuran dari pembudidaya, tingkatan teknologi dalam produksi pertanian, variasi iklim dan faktor kebijaksanaan (Ostwald dan Chen, 2006; Quan et al., 2006). Khusus di Kabupaten Pinrang, konversi sawah menjadi tambak sebagai akibat pendapatan yang lebih tinggi sebagai pembudidaya tambak daripada sebagai pembudidaya sawah (Sanusi, 2001).

Penambahan luas tambak di pantai timur Sulawesi Selatan sebagian besar berasal dari konversi hutan mangrove menjadi tambak. Sebagai contoh, Paena et al. (2008) melaporkan bahwa berdasarkan data citra satelit Landsat-7 ETM + maka terjadi penambahan luas tambak di Kabupaten Luwu Utara yaitu 4.938,84 ha pada tahun 2002 menjadi 7.838,94 ha pada tahun 2005 dan masih potensial lahan tambak sebesar 7.605,21 ha. Di pantai selatan Sulawesi Selatan tidak terjadi penambahan luas tambak yang nyata dari tahun 1995 ke 2004, karena secara umum, pantai selatan tidak memiliki potensial lahan tambak yang cukup luas.

Dari tahun 1985 sampai 1998, produksi total tambak yang tinggi berasal dari pantai barat Sulawesi Selatan. Hal ini sebagai akibat dari tambak yang lebih luas (Gambar 2) dan produktivitas tambak yang lebih tinggi (Gambar 3) di pantai barat Sulawesi Selatan. Dari tahun 1999 sampai 2004, produksi total tambak yang tinggi didapatkan di pantai timur. Ini merupakan akibat dari tambak di pantai timur yang telah digunakan untuk budidaya rumput laut dengan produksi yang tinggi sejak tahun 1999. Walaupun telah dilakukan budidaya rumput laut sejak tahun 1989 di pantai timur Sulawesi Selatan, tetapi hanya dilakukan di Kabupaten Sinjai dengan luasan sempit. Di Kabupaten Luwu, rata-rata produksi rumput laut dapat mencapai $11.000 \mathrm{~kg} / \mathrm{ha} / \mathrm{tahun}$ (Mustafa dan Sammut, 2008). Ratnawati et al. (2008) melaporkan bahwa rata-rata produksi rumput laut di Kabupaten Luwu Utara adalah $7.821 \mathrm{~kg} / \mathrm{ha} / \mathrm{tahun}$. Produksi rumput laut di pantai barat Sulawesi Selatan tidak pernah dilaporkan dari tahun 1985 sampai 2004 (Gambar 4). Produksi rumput laut di Sulawesi Selatan mulai dilaporkan dari pantai selatan yaitu di Kabupaten Takalar dan Bulukumba (Gambar 5) dan di pantai timur yaitu di Kabupaten Sinjai (Gambar 6) pada tahun 1989.

Ada tiga kelompok komoditas yang dibudidayakan di tambak Sulawesi Selatan yaitu: ikan, krustase dan rumput laut. Namun demikian, rumput laut baru dibudidayakan pada tahun 1989 di pantai selatan dan pantai timur. Produksi ketiga kelompok komoditas tersebut meningkat dari tahun 1985 sampai tahun 2000. Setelah tahun 2000, terjadi penurunan produksi kelompok ikan dan krustase, sedangkan produksi rumput laut tetap meningkat sampai tahun 2004. Penurunan produksi ikan dan krustase sebagai akibat serangan penyakit terutama terhadap udang windu yang menyebabkan penurunan produksi kelompok ikan dan krustase di Sulawesi Selatan. Penurunan produksi krustase secara drastis terjadi di pantai barat Sulawesi Selatan pada tahun 2003. Telah dilaporkan bahwa pada tahun 2003 terjadi serangan penyakit terhadap udang windu di tambak Kabupaten Luwu, Bone, Sinjai, Bulukumba, Bantaeng, Jeneponto, Takalar, Maros, Pangkep, Barru, Pinrang dan Polmas berturut-turut seluas $774 ; 311 ; 3 ; 88 ; 47 ; 431 ; 210 ; 3.291 ; 1.861 ; 1.567 ; 5.864$ dan 60 ha yang merugikan pembudidaya tambak sebesar Rp 9.006.008.306,00 (Anonim, 2003) Penurunan produksi ikan dan krustase yang sangat drastis di pantai selatan pada tahun 2000 adalah penyebab utama penurunan produksi tambak di Sulawesi Selatan. Sebab dari Gambar 5 dan 6 terlihat masih adanya peningkatan produksi ikan dan krustase di pantai barat dan timur Sulawesi Selatan.

Produktivitas tambak di ketiga pantai di Sulawesi Selatan relatif sama dari tahun 1985 sampai dengan 1998. Sejak tahun 1999, terjadi peningkatan produktivitas tambak yang sangat drastis di pantai timur Sulawesi Selatan. Hal ini sebagai akibat dari keberhasilan budidaya rumput laut di pantai timur Sulawesi Selatan seperti dijelaskan sebelumnya.

Dari tahun 1985 sampai tahun 2004, komoditas yang dilaporkan telah dibudidayakan di pantai barat Sulawesi Selatan adalah ikan dan krustase. Diantara kelompok komoditas tersebut, kelompok ikan lebih dominan sebagai produksi budidaya tambak di pantai barat Sulawesi Selatan. Demikian juga halnya dengan produksi budidaya tambak di pantai selatan Sulawesi Selatan sampai tahun 2004 dan di pantai timur sampai tahun 2002. Di pantai timur Sulawesi Selatan, produksi budidaya tambak didominasi oleh rumput laut sejak tahun 2003 (Gambar 7).

Pergeseran dominasi produksi dari ikan dan krustase ke rumput laut di pantai timur Sulawesi Selatan, sebagai akibat kondisi lahan terutama kualitas tanah yang kurang sesuai untuk budidaya ikan dan krustase. Telah banyak dilaporkan bahwa tambak di pantai timur Sulawesi Selatan didominasi oleh tanah sulfat masam (Mustafa, 2007; Mustafa et al., 2007). Tanah sulfat masam dicirikan dengan $\mathrm{pH}$ tanah rendah, kandungan unsur toksik tinggi dan unsur hara makro yang rendah. Sebagai akibatnya, produksi makanan alami yang sangat penting untuk ikan dan krustase juga sangat rendah yang berdampak pada pertumbuhan organisme yang lambat. Selain itu, kualitas tanah sulfat masam yang seperti itu juga dapat menurunkan kualitas air tambak yang bukan hanya 


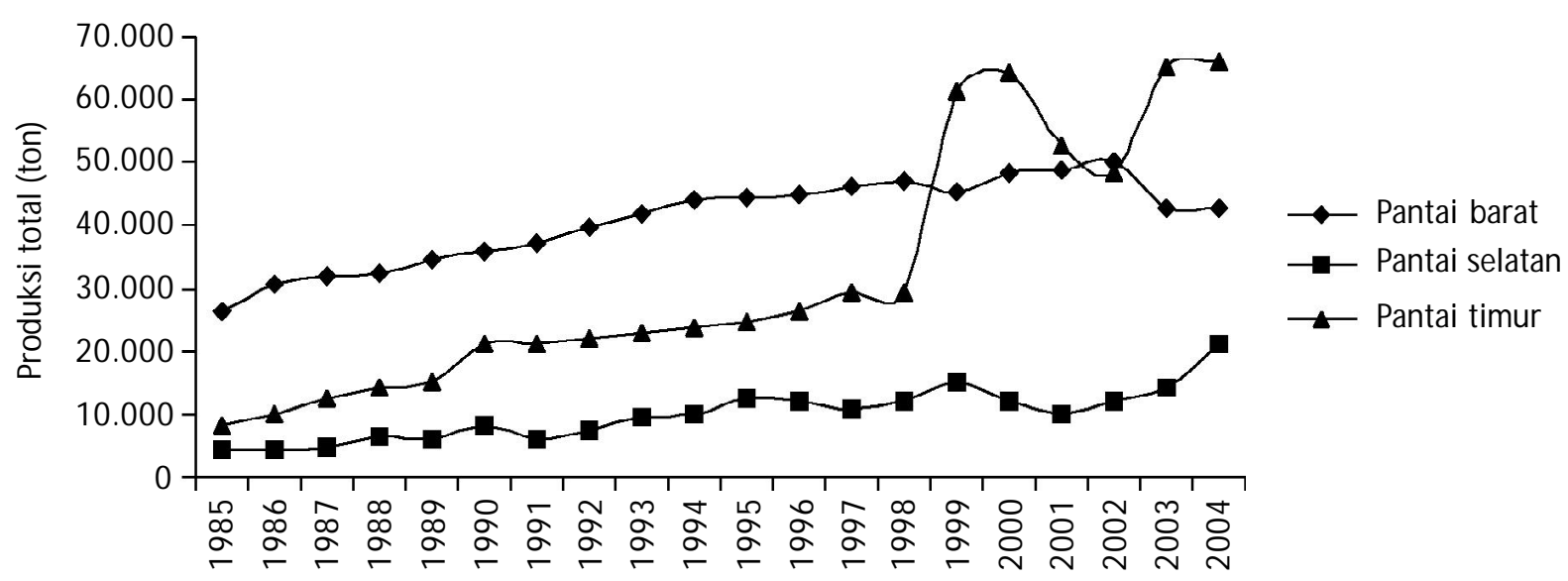

Tahun

Gambar 3. Produksi total tambak di pantai yang berbeda di Sulawesi Selatan (termasuk Sulawesi Barat) dari tahun 1985 sampai 2004

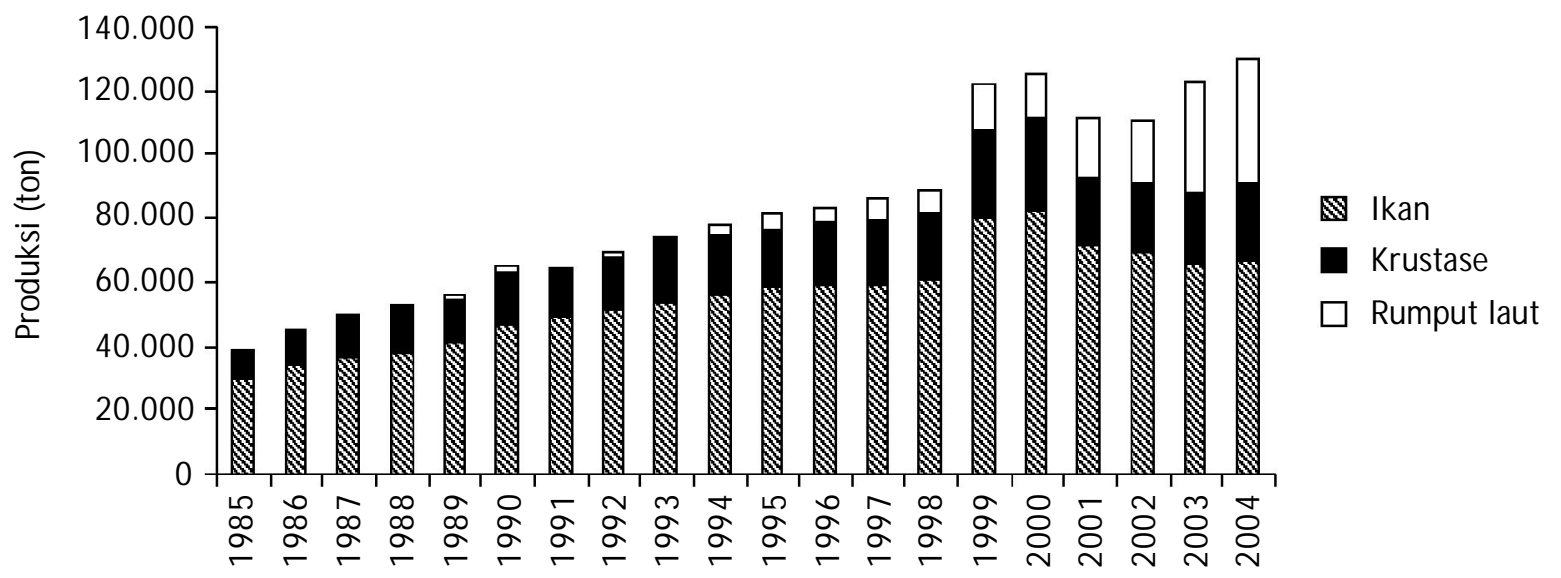

Tahun

Gambar 4. Produksi setiap kelompok komoditas di tambak Sulawesi Selatan (termasuk Sulawesi Barat) dari tahun 1985 sampai 2004

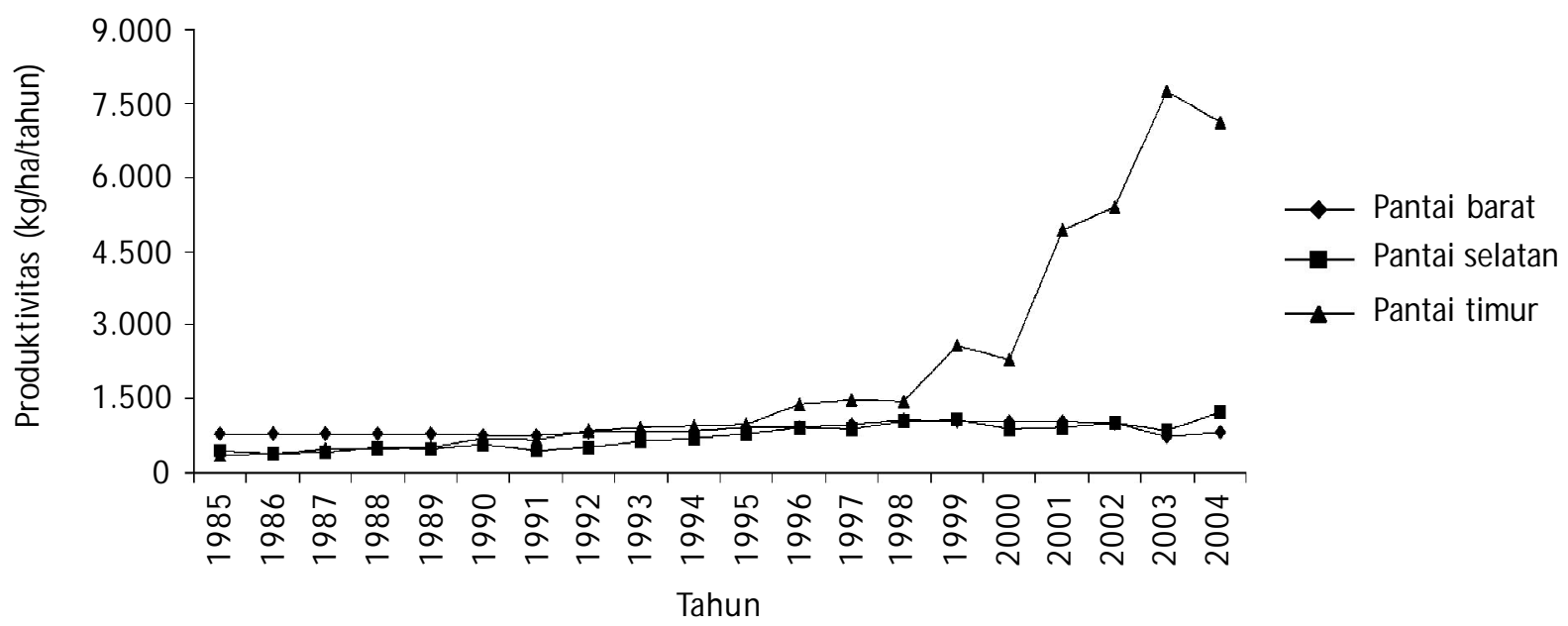

Gambar 5. Produktivitas tambak di pantai berbeda di Sulawesi Selatan (termasuk Sulawesi Barat) dari tahun 1985 sampai 2004 


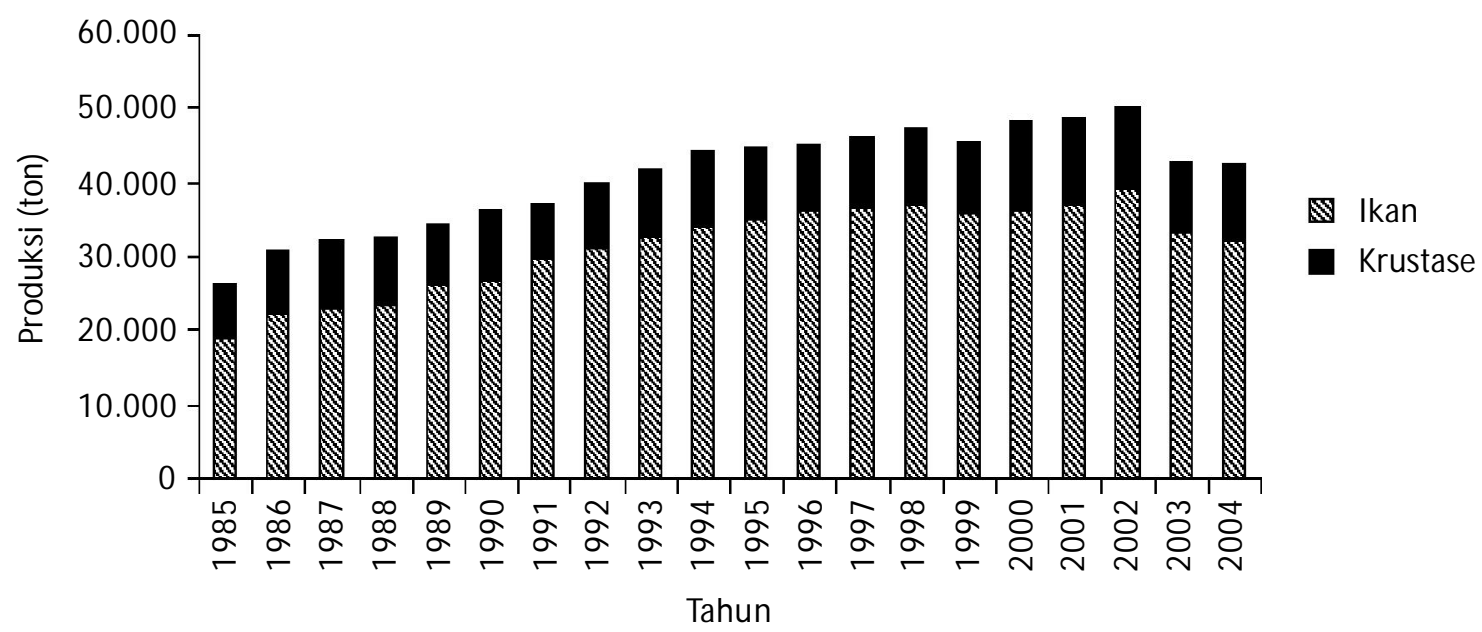

Gambar 6. Produksi budidaya tambak di pantai barat Sulawesi Selatan (termasuk Sulawesi Barat) dari tahun 1985 sampai 2004

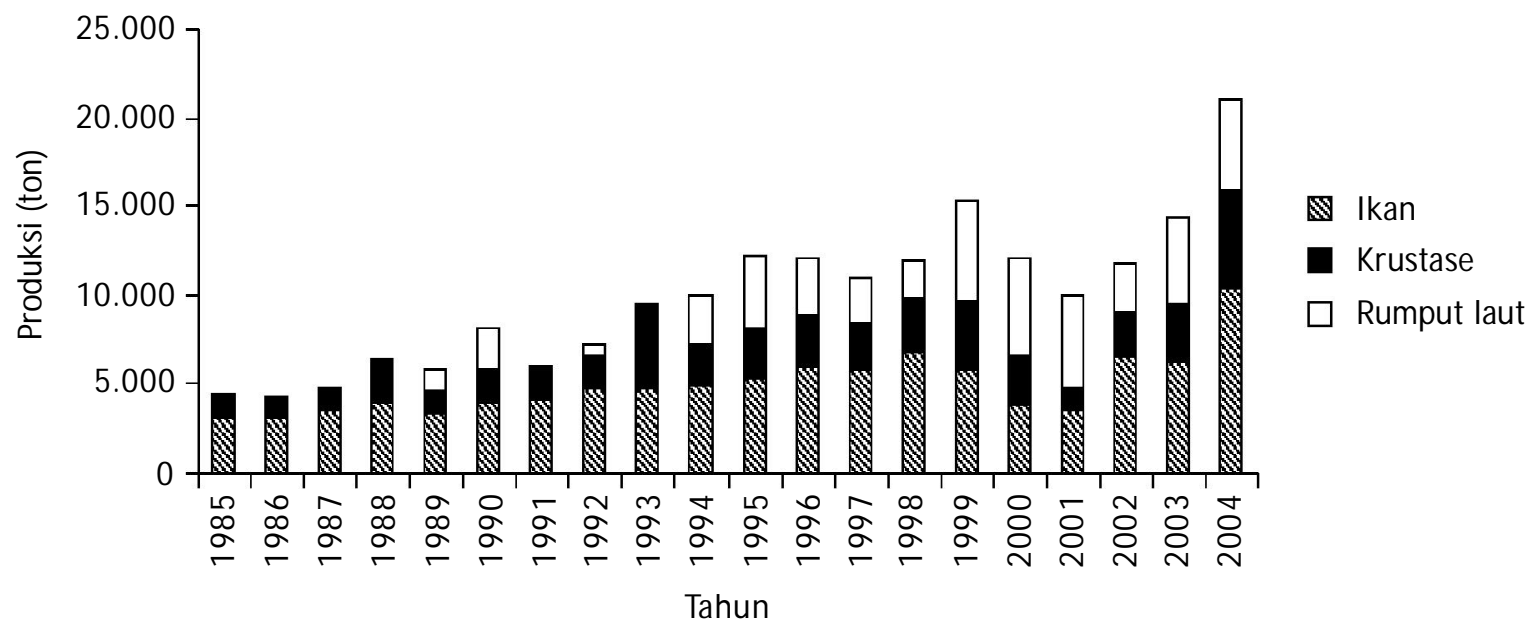

Gambar 7. Produksi budidaya tambak di pantai selatan Sulawesi Selatan dari tahun 1985 sampai 2004

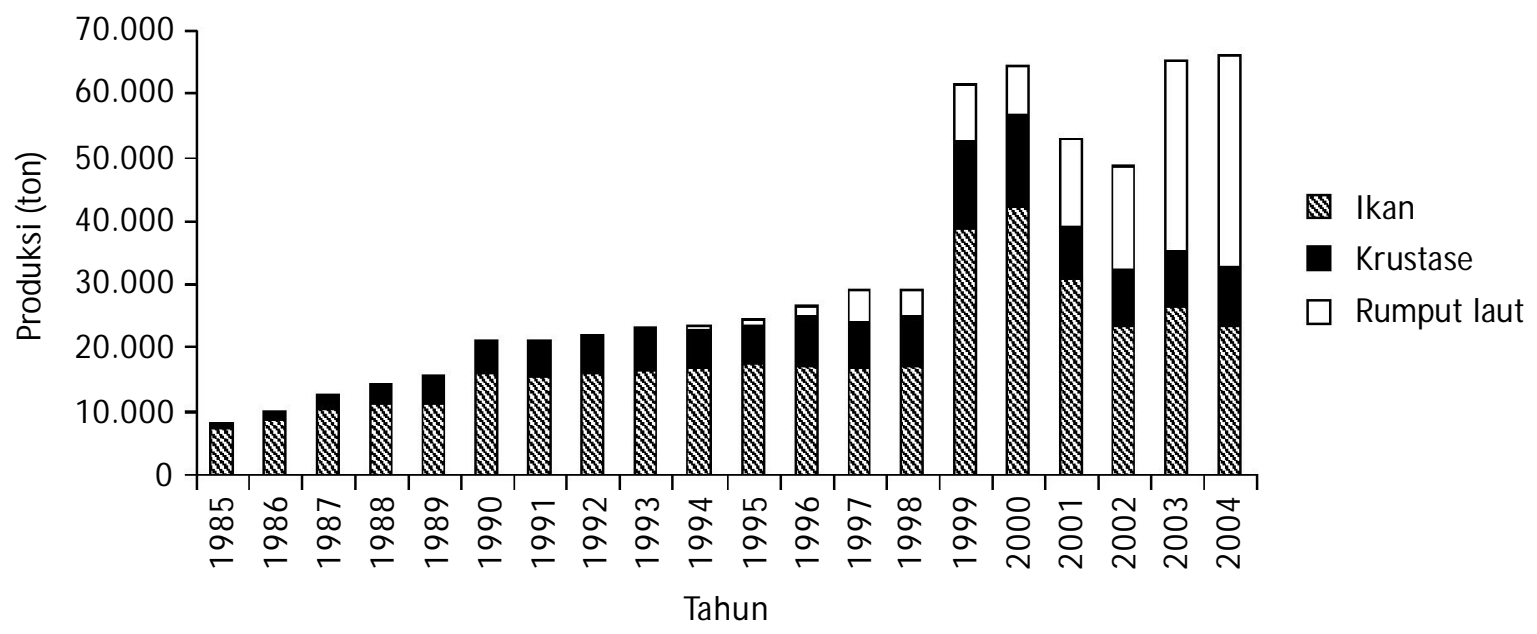

Gambar 8. Produksi budidaya tambak di pantai timur Sulawesi Selatan dari tahun 1985 sampai 2004 
menyebabkan pertumbuhan organisme akuatik yang lambat bahkan dapat mematikan. Hal ini, biasanya terjadi setelah musim kemarau yang panjang dan selanjutnya turun hujan yang menyebabkan terlarutnya hasil oksidasi pirit di tanah pematang dan masuk ke dalam tambak.

Perkembangan budidaya rumput laut tergolong cepat, sebagai akibat teknologi budidayanya yang mudah dan murah. Rumput laut termasuk tanaman air yang relatif tahan terhadap kondisi lahan yang ekstrem. Dikatakan oleh M ustafa et al. (2007) bahwa rumput laut dapat tumbuh pada kisaran pH tanah yang lebar. Kandungan Fe dan Al tanah yang tinggi pada tanah sulfat masam, tidak berdampak terlalu besar terhadap rumput laut dibandingkan dengan ikan dan krustase. Hal ini terkait dengan kemampuan tanaman air dan alga untuk menyerap logam seperti Fe dan Al (Malea \& Haritinodis, 1999; Caliceti et al., 2002; Gosavi et al., 2004). Lebih lanjut Gosavi et al. (2004) menyatakan bahwa alga dapat menyerap Fe dan Al tiga kali lipat dibandingkan dengan logam lainnya. Selain itu, tanaman air dan alga memiliki toleransi yang tinggi dibandingkan dengan ikan dan udang terhadap logam (Effendi, 2003).

Daya dukung merupakan konsep dasar yang dikembangkan untuk kegiatan pengelolaan sumberdaya alam dan lingkungan secara berkelanjutan. Konsep ini dikembangkan untuk mencegah kerusakan atau degradasi sumberdaya alam dan lingkungan. Daya dukung merupakan istilah yang lebih umum untuk karakter lingkungan dan kemampuannya dalam mengakomodasi suatu kegiatan tertentu atau laju suatu kegiatan tanpa dampak yang tidak dapat diterima (GESAM P, 2001). Penentuan daya dukung ekonomis kawasan pertambakan telah dilakukan oleh Gong et al. (1997) di Xiamen (Tiongkok) dan Prasita (2007) di Kabupaten Gresik (Jawa Timur) yang memprediksi daya dukung kawasan pertambakan dengan metode analisis regresi polinomial yang memanfaatkan data kondisi produksi secara real (riil) dan time-series (runtun waktu). Dari Gambar 5 terlihat bahwa, dari tiga kawasan pantai di mana tambak dijumpai di Sulawesi Selatan, ternyata produktivitas tambak di pantai barat Sulawesi Selatan telah mengalami penurunan. Salah satu sentra produksi tambak di pantai barat Sulawesi Selatan adalah Kabupaten Pinrang yang memiliki tambak terluas di pantai barat Sulawesi Selatan dan bahkan di Sulawesi Selatan. Produksi, luas, dan produktivitas tambak di Kabupaten Pinrang dari tahun 1985 sampai dengan 2004 dapat dilihat pada Gambar 9. Hubungan antara produktivitas dan luas tambak di Kabupaten Pinrang terlihat pada Gambar 10.

Persamaan regresi polinomial yang didapatkan dari hubungan antara luas tambak dan produktivitas tambak Kabupaten Pinrang dari tahun 1985 sampai 2004 adalah:

$Y=-611,233+0,289 X-0,000011 X^{2}$

$\left(R^{2}=0,309 ; P=0,043\right)$

Persamaan 6

di mana:

$Y=$ Produktivitas tambak $(\mathrm{kg} / \mathrm{ha})$

$X=$ Luas tambak (ha)

Daya dukung ekonomis tambak di Kabupaten Pinrang ditentukan dari kecenderungan perkembangan produksi dan luas tambak seperti diperlihatkan pada Gambar 9. Hasil analisis lebih lanjut didapatkan bahwa Kabupaten Pinrang hanya bisa mendukung luas total tambak sekitar 13.136 ha. Tampaknya daya dukung ekonomis tambak di Kabupaten Pinrang telah tercapai pada tahun 2000 di mana pada saat tersebut luas tambak mencapai 12.812 ha dengan

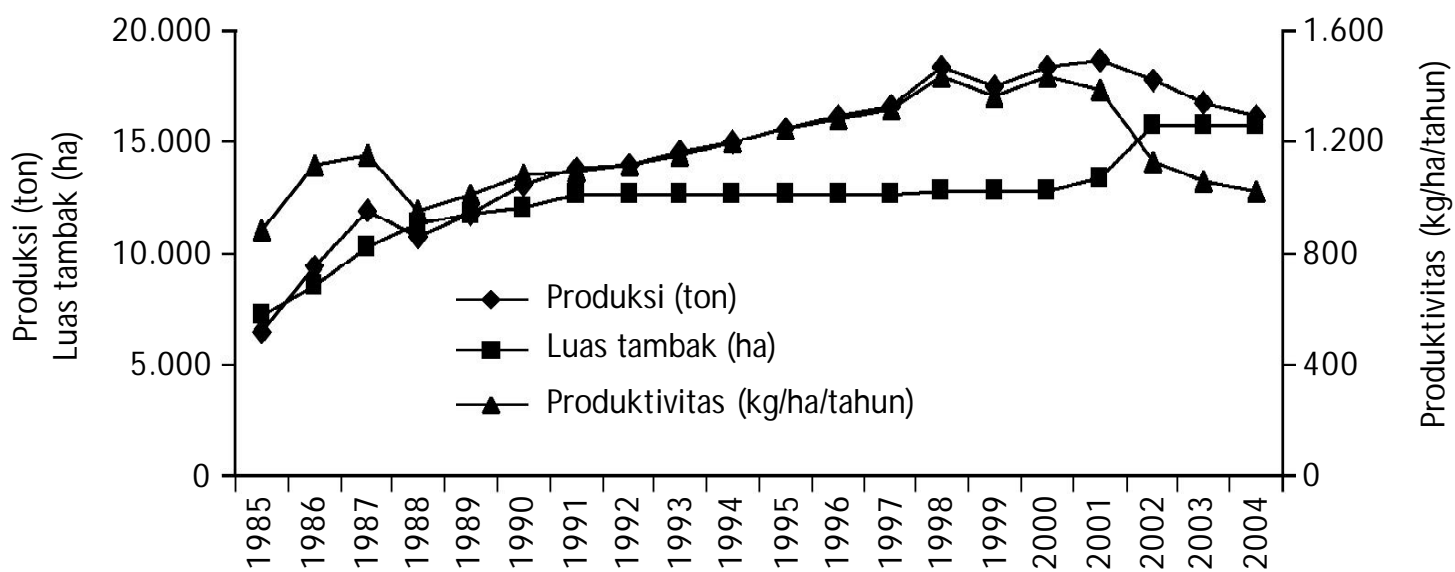

Tahun

Gambar 9. Produksi, luas tambak, dan produktivitas tambak di Kabupaten Pinrang Provinsi Sulawesi Selatan dari tahun 1985 sampai 2004 


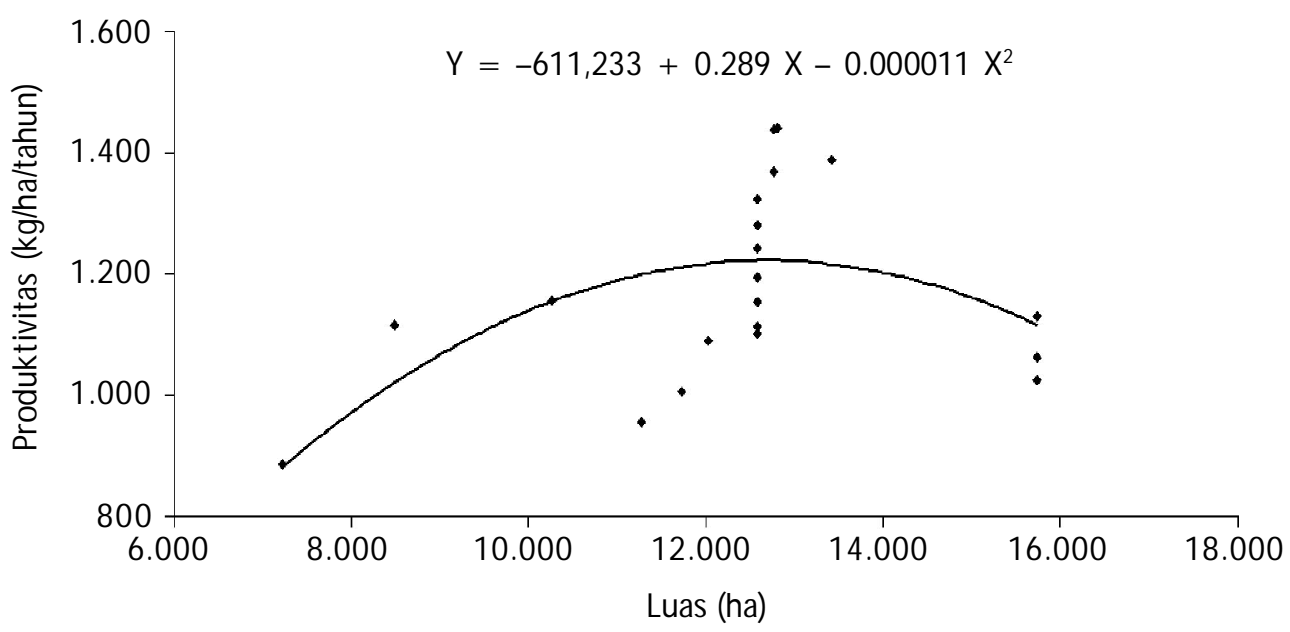

Gambar 10. Hubungan antara produktivitas dan luas tambak di Kabupaten Pinrang, Provinsi Sulawesi Selatan

produktivitas maksimum 1.440 kg/ha/tahun (Gambar 9). Kondisi ini tidak berbeda jauh dengan tambak di Kabupaten Gresik Provinsi Jawa Timur. Produksi maksimum sebesar 12.134, 4 ton terjadi pada tahun 1999 pada luas tambak $10.943,5$ ha di Kabupaten Gresik (produktivitas maksimal $1.110 \mathrm{~kg} / \mathrm{ha} /$ tahun) (Prasita, 2007). Dari Persamaan 6 dapat pula ditentukan bahwa daya dukung ekonomis tambak di Kabupaten Pinrang hanya bisa memproduksi udang dan ikan sekitar 1.286 $\mathrm{kg} / \mathrm{ha} / \mathrm{tahun}$.

\section{KESIMPULAN}

Dari 23 kabupaten/kota yang ada di Sulawesi Selatan, ternyata tambak dijumpai di 19 kabupaten/kota. Luas tambak di Sulawesi Selatan meningkat dari 64.741 ha pada tahun 1985 menjadi 111.425 ha pada tahun 2004. Produksi total tambak tertinggi pada tahun 1985 didapatkan di pantai barat yang mencapai 26.323,9 ton yang didominasi oleh ikan dan pada tahun 2004 didapatkan di pantai timur yang mencapai $66.294,1$ ton yang didominasi oleh rumput laut. Produktivitas tambak tertinggi pada tahun 1985 didapatkan di pantai barat yaitu 772,2 kg/ha/tahun dan pada tahun 2004 didapatkan di pantai timur yaitu 7.127,6 kg/ha/tahun. Daya dukung ekonomis tambak Kabupaten Pinrang yang merupakan sentra produksi budidaya tambak di Sulawesi Selatan, hanya bisa mencapai luas total tambak sekitar 13.136 ha dan memproduksi udang dan ikan sekitar 1.286 kg/ha/ tahun.

\section{UCAPAN TERIMA KASIH}

Diucapkan terima kasih kepada Proyek ACIAR FIS/ 2002/076 "Land Capability Assessment and Classification for Sustainable Pond-based, Aquaculture Systems" atas biaya studi ini.

\section{DAFTAR PUSTAKA}

Anonim. 1985-2006. Laporan Statistik Perikanan Sulawesi Selatan. Dinas Perikanan dan Kelautan Propinsi Sulawesi Selatan, Makassar.

Anonim. 2008. Kebangkitan budidaya udang windu di Sulsel tahun 2008. Dinas Perikanan dan Kelautan Provinsi Sulawesi Selatan, Makassar. $17 \mathrm{hlm}$.

Caliceti, M., Argese, E., Sfriso, A., \& Pavoni, B. 2002. Heavy metal contamination in the seaweeds of the Venice lagoon. Chemosphere 47, 443- 454.

Effendi, H. 2003. Telaah KualitasAir bagi Pengelolaan Sumber Daya dan Lingkungan Perairan. Penerbit Kanisius, Yogyakarta. $258 \mathrm{hlm}$.

GESAM P (IM O/FAO/UNESCO-IOC/WMO/WHO/IAEA/UN/ UNEP Joint Group of Experts on the Scientific Aspects of Marine Environmental Protection). 2001. Planning and Management for Sustainable Coastal Aquaculture Development. Food and Agriculture Organization of the United Nations, Rome. http://www.fao.org/docrep/ 005/y1818e/y1818e00.htm. Diakses 17/06/2009.

Gong, C., Shaojing, L., Yuanshao, L., Shengyun, Y., \& Zhenzu, X. 1997. Estimation of carrying capacity for mariculture development in Xiamen, People's Republic of China. In: The Regional Workshop on Partnerships in the Application of Integrated Coastal Management, 12-14 November 1997. 167 pp.

Gosavi, K., Sammut, J., Gifford, S., \& Jankowski, J. 2004. Macroalgal biomonitors of trace metal contamination in acid sulfate soil aquaculture ponds. Science of the Total Environment 324(1-3), 25-39. 
Malea, P. \& Haritonidis, S. 1999. Metal content in Enteromorpha linza (Linnaeus) in Themaikos Gulf (Greece). Hydrobiologia 394, 103-112.

Mustafa, A. 2007. Improving Acid Sulfate Soils for Brackish Water Ponds in South Sulawesi, Indonesia. Ph.D. Thesis. The University of New South Wales, Sydney. 418 pp.

Mustafa, A., Sapo, I., Hasnawi, \& Sammut, J. 2007. Hubungan antara faktor kondisi lingkungan dan produktivitas tambak untuk penajaman kriteria kelayakan lahan: 1. kualitas air. J. Ris. Akuakultur 2(3): 289-302.

Mustafa, A., Utojo, Hasnawi, \& Rachmansyah. 2006. Validasi data luas lahan budidaya tambak di Kabupaten Maros dan Pangkep Provinsi Sulawesi Selatan dengan menggunakan teknologi penginderaan jauh dan sistem informasi geografis. J. Ris. Akuakultur 1(3), 419-430.

Mustafa, A. \& Sammut, J. 2008. Dominant factors that effect on the seaweed (Gracilaria verrucosa) production in acid sulfate soils-affected ponds of Luwu Regency, Indonesia. Research Institute for Coastal Aquaculture, Maros.

Nasoetion, L.I. \& Wagner, M. 1985. Struktur Tata Ruang Wilayah yang Memusat: Penyebab dan Pengaruhnya pada Daerah Belakang (Studi Kasus Kodya Tebing Tinggi Sumatera Utara. Tesis. Fakultas Pascasarjana, Institut Pertanian Bogor, Bogor.

Ostwald, M. \& Chen, D. 2006. Land-use change: Impacts of climate variations and policies among small-scale farmers in the Loess Plateau, China. Land Use Policy $23,361-371$.
Paena, M., Mustafa, A., Hasnawi, \& Rachmansyah. 2008. Validasi luas lahan tambak di Kabupaten Pinrang, Provinsi Sulawesi Selatan dengan menggunakan teknologi penginderaan jauh dan sistem informasi geografis. J. Ris. Akuakultur 2(3), 329-340.

Paena, M., Mustafa, A., Hasnawi, \& Rachmansyah. 2008. Validasi luas periodik dan penentuan luas potensi tambak di Kabupaten Luwu Utara Provinsi Sulawesi Selatan dengan menggunakan teknologi penginderaan jauh dan sistem informasi geografis. J. Ris. Akuakultur Akuakultur 3(1), 137-146.

Prasita, V.D. 2007. Analisis Daya Dukung Lingkungan dan Optimalisasi Pemanfaatan Wilayah Pesisir untuk Pertambakan di Kabupaten Gresik. Disertasi. Sekolah Pascasarjana, Institut Pertanian Bogor, Bogor. $145 \mathrm{hlm}$.

Ratnawati, E., Mustafa, A., \& Rachmansyah. 2008. Faktor status pembudidaya, kondisi dan pengelolaan tambak yang berpengaruh terhadap produksi rumput laut (Gracilaria verrucosa) di tambak tanah sulfat masam Kabupaten Luwu Utara Provinsi Sulawesi Selatan. J. Ris. Akuakultur 3(2), 275-287.

Sanusi, A. 2001. Konversi Lahan Sawah Menjadi Tambak Ditinjau dari Pendapatan Petani. Tesis Magister. Program Pasca Sarjana Universitas Hasanuddin, Makassar. $74 \mathrm{hlm}$.

Sudjana. 1996. M etoda Statistika. Edisi keenam. Penerbit Tarsito, Bandung. $508 \mathrm{hlm}$.

Quan, B., Chen, J.F., Qiu, H.L., Römkens, M.J.M., Yang, X.Q., Jiang, S.F., \& Li, B.C. 2006. Spatial-temporal pattern and driving forces of land use changes in Xiamen. Pedosphere 16(4), 477-488. 